\title{
Functional and Radiographic Results of Hemiarthroplasty in the Treatment of Hallux Rigidus of the First Metatarsophalangeal Joint
}

\author{
Birinci Metatarsofalengeal Eklemin Halluks Rigidus Hastalığının \\ Tedavisinde Hemiartroplastinin Fonksiyonel ve Radyografik Sonuçları
}

Gökçer UZER id, Fatih YILDIZ id, Jotyar ALİ id

Department of Orthopedics and Traumatology, Bezmialem Vakif University School of Medicine, İstanbul, Turkey

\section{ABSTRACT}

Objective: The purpose of this study was to evaluate changes in the radiological, clinical, and functional results following the application of hemiarthroplasty in patients with grade 3 or 4 first metatarsophalangeal joint osteoarthritis.

Methods: Twenty-one feet of nineteen patients who were who were diagnosed as grade 3 or 4 hallux rigidus and treated with hemiarthroplasty, between January 2013 and December 2015, were retrospectively evaluated. Functional results [visual analog scale (VAS) and American Orthopedic Foot and Ankle Society (AOFAS) scores, Short Form-12 (SF12) physical and mental scores], clinical results (ranges of dorsiflexion and plantar flexion), and radiological results (osteolysis, loosening, hallux valgus angles (HVA), and intermetatarsal angles (IMA)) were evaluated at their follow-up.

Results: The mean follow-up period was 24 (range: 12-66) months. The mean ranges of flexion was increased from $6^{\circ}$ (range: $0^{\circ}-20^{\circ}$ ) to $8^{\circ}\left(\right.$ range: $\left.0^{\circ}-20^{\circ}\right)$ and ranges of extension from $4^{\circ}$ (range; $0^{\circ}-10^{\circ}$ ) to $7^{\circ}$ (range: $0^{\circ}-30^{\circ}$ ), postoperatively. Preoperative and postoperative values of the mean IMA $\left(9^{\circ}\right.$ vs. $\left.11^{\circ}\right)$ and HVA $\left(18^{\circ}\right.$ vs. $\left.13^{\circ}\right)$ did not change significantly. The mean AOFAS scores increased from 72 to 96 $(\mathrm{p}=0.003)$. The mean VAS, SF12-MCS, and SF12-PCS scores were 7.8 (range: 4-10), 42.7 (range: 33.8-55.7), and 51.1 (range, 36.761.2), postoperatively and comparisons to their preoperative values were not significant. Radiographic follow-up did not show findings of osteolysis around the prosthesis or loosening in any patient.

Conclusion: In the treatment of hallux rigidus with hemiarthroplasty, although postoperative range of movement was found to be limited, patient satisfaction and pain levels were improved in all patients.

Keywords: First metatarsophalangeal joint osteoarthritis, hallux rigidus, hemiarthroplasty

\section{öz}

Amaç: Bu çalışmanın amacı birinci metatarsofalangeal eklem evre 3 veya 4 osteoartritinin tedavisinde uygulanan hemiartroplasti yönteminin radyolojik, klinik ve fonksiyonel sonuçlarını değerlendirmektir.

Yöntemler: 2013 Ocak ile 2015 Aralık tarihleri arasında evre 3 veya 4 halluks rigidus tanısı almış ve hemiartroplasti ile tedavi edilmiş 19 hastanın 21 ayağı geriye dönük olarak değerlendirildi. Fonksiyonel sonuçlar (VAS ve AOFAS skorları, SF12 fiziksel ve mental skorları), klinik sonuçlar (dorsifleksiyon ve plantar fleksiyon eklem hareket açıklıkları) ve radyolojik sonuçlar (osteoliz, gevşeme, HVA ve IMA açıları) takiplerde araştırıldı.

Bulgular: Ortalama takip süresi 24 (12-66) ay idi. Takiplerde ortalama fleksiyon $6^{\circ}\left(0^{\circ}-20^{\circ}\right)$ den $8^{\circ}\left(0^{\circ}-20^{\circ}\right)$ ye ve ekstansiyon $4^{\circ}\left(0^{\circ}-10^{\circ}\right)$ den $7^{\circ}\left(0^{\circ}-30^{\circ}\right)$ ye yükseldi. Preoperatif ve postoperatif IMA $\left(9^{\circ}\right.$ ve $\left.11^{\circ}\right)$ ve HVA $\left(18^{\circ}\right.$ ve $\left.13^{\circ}\right)$ dereceleri arasinda istatistiksel fark yoktu. Ortalama AOFAS skoru 72'den 96'a yükseldi ( $\mathrm{p}=0,003)$. takiplerde ortalama VAS, SF12-mental ve SF12fiziksel skorları sırası ile 7,8 (4-10), 42,7 $(33,8-55,7)$ ve 51,1 $(36,7-61,2)$ idi ve ameliyat öncesi değerler ile karşılaştırıldığında anlamlı fark bulunmadı. Radyolojik takiplerde protez çevresi osteoliz veya gevşemeye rastlanmadi.

Sonuç: Halluks rijidusun hemiartroplasti ile tedavisinde her ne kadar ameliyat sonrası eklem hareket açıklığı kısıtlı kalsa da tüm hastalarımızda ağrı seviyesinde azalma ve hasta memnuniyetinde artış görülmüştür.

Anahtar kelimeler: Birinci metatarsofalangeal eklem osteoartriti, halluks rijidus, hemiartroplasti

\section{Introduction}

Hallux rigidus is a clinical situation manifesting as restricted range of motion and inflammation associated with advanced arthrosis. It is characterized by the formation of osteophytes, loss of cartilage, and degeneration of the first metatarsophalangeal ( $\left.1^{\text {st }} \mathrm{MTP}\right)$ joint with pain and restricted movement $(1,2)$. While the joint range of movement $(\mathrm{ROM})$ is generally preserved in plantar flexion, a loss of dorsiflexion develops with the mechanical block effect of osteophytes.

Cite this article as: Uzer G, Yıldız F, Ali J. Functional and Radiographic Results of Hemiarthroplasty in the Treatment of Hallux Rigidus of the First Metatarsophalangeal Joint. Bezmialem Science 2018; 6(3): 176-80. 
Several classifications are used in the grading of hallux rigidus. In 1988, Hattrup and Johnson (3) separated hallux rigidus into three grades based on radiological findings. Then, Coughlin and Shurnas (4) recommended grading using both radiographic and clinical evaluations, and this system is the most widely accepted for assisting in the selection of surgical treatment (Table 1). According to this classification, grades 0-2 can be followed up with non-surgical treatment options such as non-steroid anti-inflammatory drugs (NSAID) and shoe modifications (5). For advanced grades, surgical treatments may include cheilectomy, which yields successful results in the early stages as it prevents constriction of osteophytes in the dorsal part (6); and for grade 3 and 4s, Keller resection arthroplasty (7), phalangeal and metatarsal osteotomy (8), joint distraction, arthrodesis $(9,10)$, and total or partial arthroplasty are the preferred methods (11-13).

The aim of this study was to evaluate the changes in radiological, clinical, and functional results following the application of hemiarthroplasty in patients with grade 3 or $41^{\text {st }}$ MTP joint osteoarthritis.

\section{Methods}

This retrospective study was performed according to the Declaration of Helsinki and received Institutional Review Board approval. We evaluated patients who were diagnosed with grade 3-4 hallux rigidus and treated with hemiarthroplasty, between January 2013 and December 2015 (Figure 1. a, b). Patients were excluded from the study if they had not attended regular outpatient clinic follow-up, if different implants had been used, or if total joint arthroplasty had been applied. In total, 19 patients were included in this study, comprising 4 males and 15 females, with a mean age of 56 (range: 47-73) years. Hemiarthroplasty procedures $\left(\mathrm{HemiCAP}^{\circ}\right.$, Arthrosurface, Franklin, MA, USA) were applied to $211^{\text {st }}$ MTP joints of the 19 patients; 12 to the right foot and 9 to the left foot. All the operations were performed in the same hospital by two different surgeons. All the patients signed informed consent forms before surgery and were operated under spinal anesthesia. On postoperative day one, active and passive $1^{\text {st }}$ MTP joint ROM exercises were initiated and from the end of the first week, walking was recommended with full weight-bearing and two crutches and special wedge shoe modifications.

In the subsequent period, exercises to increase ROM were recommended. Patients were called for outpatient clinic follow-up examinations at 1,3 , and 6 weeks, then at 3, 6, and 12 months for evaluating ROM, wound site problems, and pain. Standing anteroposterior and lateral radiographs were acquired at the 6-week, 3-month, and 12-month examinations (Figure 2. a, b). All the patients were evaluated clinically with respect to plantar flexion and dorsiflexion ROM, and radiologically on the radiographs taken with respect to osteolysis, loosening, and change in the hallux valgus angles (HVA) and the intermetatarsal angles (IMA) (Figure 3). A visual analog scale (VAS) was used to evaluate pain status, and functional results were assessed using the American Orthopedic Foot and Ankle Society, (AOFAS) scoring system. Patient satisfaction was evaluated using the Short Form-12 (SF-12) in face-to-face interviews to evaluate the physical (SF12-PCS) and mental (SF12-MCS) status. Patients were also questioned whether they had experienced difficulties in shoe selection in the postoperative period.

Table 1. Clinical and radiological staging in Hallux valgus

\begin{tabular}{|c|c|c|c|}
\hline Stage & Dorsiflexion & Radiological findings & Clinical findings \\
\hline 0 & $\begin{array}{l}\sim 40^{\circ}-60^{\circ} \text { or } 10 \%-20 \% \text { lower } \\
\text { than normal side }\end{array}$ & Normal & No pain, only restriction in ROM \\
\hline 1 & $\begin{array}{l}\sim 30^{\circ}-40^{\circ} \text { or } 20 \%-50 \% \text { lower } \\
\text { than normal side }\end{array}$ & $\begin{array}{l}\text { Dorsal osteophyte is the main finding, mild } \\
\text { narrowing of the joint space, mild sclerosis } \\
\text { and mild flattening of the metatarsal head }\end{array}$ & $\begin{array}{l}\text { Rarely painful, especially during the } \\
\text { end-levels of the dorsiflexion and } \\
\text { plantar flexion }\end{array}$ \\
\hline 2 & $\begin{array}{l}\sim 10^{\circ}-30^{\circ} \text { or } 50 \%-75 \% \text { lower } \\
\text { than normal side }\end{array}$ & $\begin{array}{l}\text { Dorsal, lateral or medial osteophytes show } \\
\text { flattening of the metatarsal head. In the } \\
\text { lateral X-ray, } 3 / 4 \text { of the articular cartilage is } \\
\text { preserved. Mild or moderate narrowing of the } \\
\text { joint space. Sesamoids are usually affected. }\end{array}$ & $\begin{array}{l}\text { Moderate or severe continuous } \\
\text { pain, which occurs with the } \\
\text { hyperextension and hyperflexion. }\end{array}$ \\
\hline 3 & $\begin{array}{l}\leq 10^{\circ} \text { or } 75 \%-100 \% \text { lower } \\
\text { than normal side. Usually } \\
\text { severe restriction in plantar } \\
\text { flexion of the MTF joint. }\end{array}$ & $\begin{array}{l}\text { Similar to stage } 2 \text { but severe narrowing } \\
\text { in the joint space, cyst formation around } \\
\text { the joint and more than } 1 / 4 \text { of the dorsal } \\
\text { cartilage is narrowed on the lateral X-ray. } \\
\text { Widening of the sesamoids with cysts } \\
\text { and roughness. }\end{array}$ & $\begin{array}{l}\text { Continuous pain and severe } \\
\text { restriction of the ROM. Pain is more } \\
\text { apparent with the hyperextension } \\
\text { and hyperflexion. No pain in the } \\
\text { mid-ranges of the motion. }\end{array}$ \\
\hline 4 & Similar to Stage 3 & Similar to Stage 3 & $\begin{array}{l}\text { Similar to grade } 3 \text { but pain becomes } \\
\text { even in the mid-ranges of the motion. }\end{array}$ \\
\hline
\end{tabular}




\section{Statistical analysis}

Statistical analysis of the preoperative and postoperative scores and changes in angles were applied using the Wilcoxon signed-rank test.

\section{Results}

The mean follow-up period of the 21 feet of 19 patients was 24 (range: 12-66) months. Preoperatively, the mean ranges of flexion of the $1^{\text {st }}$ MTP joint was $6^{\circ}$ (range: $0^{\circ}-20^{\circ}$ ) and exten-
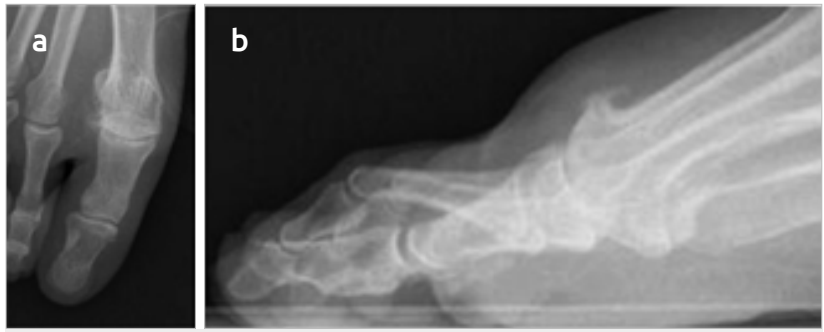

Figure 1. a, b. Anteroposterior (a) and lateral (b) radiographs of a patient with the hallux rigidus of the first metatarsophalangeal joint
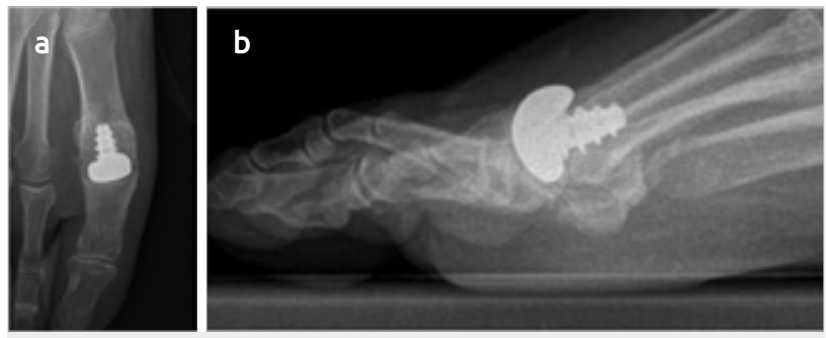

Figure 2. a, b. Postoperative anteroposterior (a) and lateral (b) radiographs of the same patient after implantation of the hemiarthroplasty

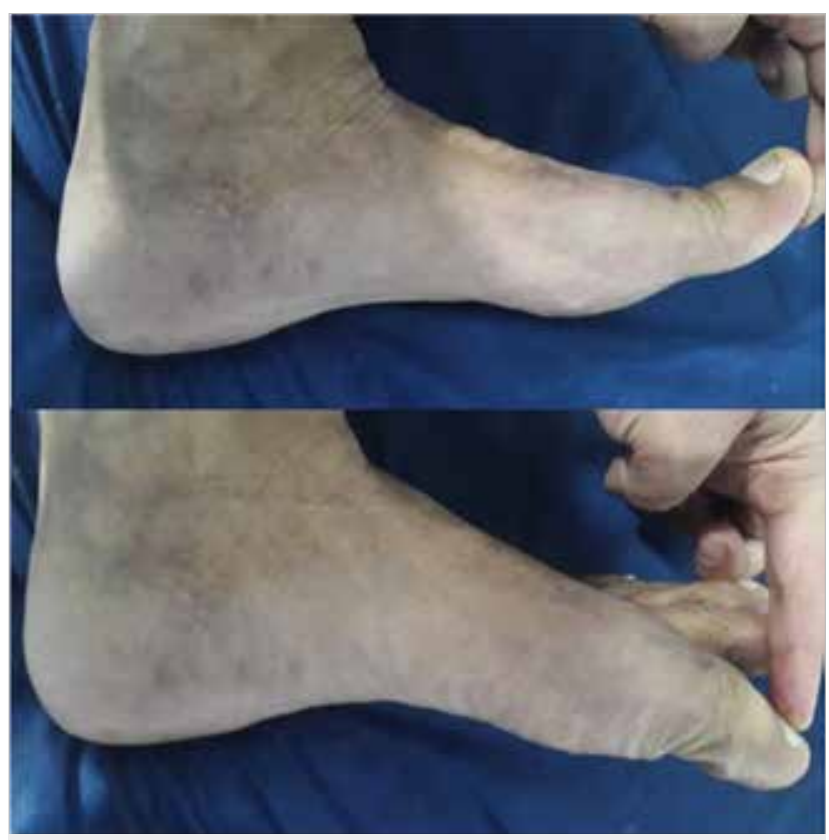

Figure 3. Dorsiflexion and plantar flexion of the metatarsophalangeal joint with the hemiarthroplasty sion was $4^{\circ}$ (range: $0^{\circ}-10^{\circ}$ ). At the final follow-up, they were measured as $8^{\circ}$ (range: $0^{\circ}-20^{\circ}$ ), and extension as $7^{\circ}$ (range: $\left.0^{\circ}-30^{\circ}\right)$.

The mean IMA was $9^{\circ}$ (range: $4^{\circ}-15^{\circ}$ ) preoperatively and $11^{\circ}$ (range: $6^{\circ}-16^{\circ}$ ) postoperatively. The mean HVA was $18^{\circ}$ (range: $7^{\circ}-30^{\circ}$ ) preoperatively and $13^{\circ}$ (range: $7^{\circ}-22^{\circ}$ ) postoperatively. The mean AOFAS scores increased from 72 (range: 82-92) to 96 (range: 79-100), postoperatively. The mean VAS, SF12-MCS, and SF12-PCS scores were 7.8 (range: 4-10), 42.7 (range: 33.8-55.7), and 51.1 (range: 36.7-61.2) postoperatively.

The increase in the mean AOFAS scores from the preoperative to postoperative period was statistically significant $(\mathrm{p}=0.003)$, whereas changes in ROM, IMA, and HVA were not statistically significant $(\mathrm{p}=0.478, \mathrm{p}=0.106)$. Although $53.8 \%$ of the patients reported problems of shoe selection and the need to wear special shoes, the mean VAS score was found to be 7.8 (range: $4-10$ ), and $72 \%$ of the patients stated that they were satisfied with the operation.

A statistically significant correlation was determined between the preoperative AOFAS and preoperative HVA, the change in postoperative HVA, and the postoperative AOFAS $(\mathrm{p}=0.001, \mathrm{p}=0.013, \mathrm{p}=0.011$, respectively). No statistically significant correlation was found between preoperative values of body mass index, age, IMA, HVA, and the postoperative AOFAS and VAS scores.

Radiographic follow-ups did not indicate osteolysis around the prosthesis or loosening in any patient. Two patients complained of persistent pain and joint stiffness, postoperatively. They were treated with plate arthrodesis of the $1^{\text {st }}$ MTP joint at the third and seventh months after their initial surgeries, and their complaints resolved.

\section{Discussion}

In the treatment of advanced stage osteoarthritis of the $1^{\text {st }}$ MTP joint, surgical options should be considered if conservative treatment fails. Although good results have been reported in the literature from arthrodesis, which is applied as the preferred choice in patients with a high functional demand, kinematic studies have shown arthrodesis to cause a shortening in step length and loss of ankle plantar flexion in the toe-off phase (14). Complications have also been reported such as malalignment, non-union, and degeneration of the adjacent joints $(9,10)$.

High failure rates have been reported of $1^{\text {st }}$ MTP joint arthroplasty applied in the early stages of the disease (15), but with recent developments of implants compatible with foot biomechanics, higher success rates have been reported. Implants have now been developed as $4^{\text {th }}$ generation. The $1^{\text {st }}$ and $2^{\text {nd }}$ generation were produced from silicone, but many complications were reported to be associated with these implants such as wear, early breakage of the implant, synovitis, and osteolysis $(16,17)$. The $3^{\text {rd }}$ generation were developed as metallic 
press-fit implants, and the $4^{\text {th }}$ generation are metallic implants combined with a stem $(18,19)$.

As hemiarthroplasty is applied to a single surface; although minimal bone defect and minimal toe length are provided, it facilitates the transfer to arthrodesis when necessary (20). Very few studies have been published related to the mid-term results of hemiarthroplasty. In a study by Aslan et al. (11) of hemiCAP applied to patients, after a 37-month follow-up period, the mean AOFAS score was reported as 85.1 and the ROM had increased to $40^{\circ}$ in the postoperative period.

In the current study with a mean 24-month of follow-up (range: 12-66 months), the mean postoperative AOFAS score was 97 (range: 79-100). This difference in the AOFAS scoring can be considered to be due to most of the patients in the current study having advanced arthritis and not having a high level of activity. The mean postoperative VAS score was 7.8 (range: 4-10), and the SF-12 scores were 42.7 (range: 33.855.7) for MCS and 51.1 (range; 36.7-61.2) for PCS, which reflected recovery and patient satisfaction and supported reduction in postoperative pain. However, despite improvement in AOFAS scores, the mean ROM was $15^{\circ}$ (range: $0^{\circ}$ $30^{\circ}$ ), which is not similar to that reported in the literature. This can be considered to be related to insufficient rehabilitation during the postoperative period.

\section{Conclusion}

In the treatment of hallux rigidus with hemiarthroplasty, although postoperative ROM was found to be limited, almost half of the patients changed their choice of footwear and there was a high level of patient satisfaction with reduction in pain. As a result of implant developments, the rates of loosening and osteolysis have reduced, and hemiarthroplasty can be considered to be a good alternative for the treatment of hallux rigidus in patients with low activity levels.

Ethics Committee Approval: Authors declared that the research was conducted according to the principles of the World Medical Association Declaration of Helsinki "Ethical Principles for Medical Research Involving Human Subjects", (amended in October 2013).

Informed Consent: Written informed consent was obtained from all patients who participated in this study.

Peer-review: Externally peer-reviewed.

Author Contributions: Concept - G.U.; Design - G.U., J.A.; Supervision - F.Y.; Resources - G.U.; Materials - F.Y., J.A.; Data Collection and/or Processing - G.U., J.A.; Analysis and/or Interpretation - G.U., J.A.; Literature Search - J.A.; Writing Manuscript - G.U., F.Y.; Critical Review - F.Y.

Conflict of Interest: Authors have no conflicts of interest to declare.

Financial Disclosure: The authors declared that this study has received no financial support.
Etik Komite Onayı: Yazarlar çalışmanın World Medical Association Declaration of Helsinki "Ethical Principles for Medical Research Involving Human Subjects”, (amended in October 2013) prensiplerine uygun olarak yapıldığını beyan etmişlerdir.

Hasta Onamı: Yazılı hasta onamı bu çalışmaya katılan tüm hastalardan alınmıştır.

Hakem Değerlendirmesi: Dış bağımsız.

Yazar Katkıları: Fikir - G.U.; Tasarım - G.U., J.A.; Denetleme F.Y.; Kaynaklar - G.U.; Malzemeler - F.Y., J.A.; Veri Toplanması ve/ veya İşlemesi - G.U., J.A.; Analiz ve/veya Yorum - G.U., J.A.; Literatür Taraması - J.A.; Yazıyı Yazan - G.U., F.Y.; Eleştirel İnceleme - F.Y.

Çıkar Çatışması: Yazarlar çıkar çatışması bildirmemişlerdir.

Finansal Destek: Yazarlar bu çalışma için finansal destek almadıklarını beyan etmişlerdir.

\section{References}

1. Hasselman CT, Shields N. Resurfacing of the First Metatarsal Head in the Treatment of Hallux Rigidus. Techniques in Foot \& Ankle Surgery 2008; 7: 31-40. [CrossRef]

2. Maffulli N, Papalia R, Palumbo A, Del Buono A, Denaro V. Quantitative review of operative management of hallux rigidus. Br Med Bull 2011; 98: 75-98. [CrossRef]

3. Hattrup SJ, Johnson KA. Subjective results of hallux rigidus following treatment with cheilectomy. Clin Orthop Relat Res 1988: 182-91. [CrossRef]

4. Coughlin MJ, Shurnas PS. Hallux rigidus. Grading and longterm results of operative treatment. J Bone Joint Surg Am 2003; 85: 2072-88. [CrossRef]

5. Shurnas PS. Hallux Rigidus: Etiology, Biomechanics, and Nonoperative Treatment. Foot Ankle Clin 2009; 14: 1-8. [CrossRef]

6. Baumhauer JF. Dorsal cheilectomy of the first metatarsophalangeal joint in the treatment of hallux rigidus. Operative Techniques Orthopaedics 1999; 9: 26-32. [CrossRef]

7. Mackey RB, Thomson AB, Kwon O, Mueller MJ, Johnson JE. The Modified Oblique Keller Capsular Interpositional Arthroplasty for Hallux Rigidus. J Bone Joint Surg Am 2010; 92: 1938-46. [CrossRef]

8. Kilmartin TE. Phalangeal osteotomy versus first metatarsal decompression osteotomy for the surgical treatment of hallux rigidus: A prospective study of age-matched and condition-matched patients. J Foot Ankle Surg 2005; 44: 2-12. [CrossRef]

9. Coughlin MJ. Arthrodesis of the first metatarsophalangeal joint with mini-fragment plate fixation. Orthopedics 1990; 13: 1037-44.

10. Coughlin MJ, Abdo RV. Arthrodesis of the first metatarsophalangeal joint with Vitallium plate fixation. Foot Ankle Int 1994; 15: 18-28. [CrossRef]

11. Aslan H, Citak M, Bas EG, Duman E, Aydin E, Ates Y. Early results of $\operatorname{HemiCAP}((\mathrm{R}))$ resurfacing implant. Acta Orthop Traumatol Turc 2012; 46: 17-21. [CrossRef]

12. Brewster M. Does total joint replacement or arthrodesis of the first metatarsophalangeal joint yield better functional results? A systematic review of the literature. J Foot Ankle Surg 2010; 49: 546-52. [CrossRef] 
13. Keiserman LS, Sammarco VJ, Sammarco GJ. Surgical treatment of the hallux rigidus. Foot Ankle Clin 2005; 10: 75-96. [CrossRef]

14. DeFrino PF, Brodsky JW, Pollo FE, Crenshaw SJ, Beischer AD. First metatarsophalangeal arthrodesis: a clinical, pedobarographic and gait analysis study. Foot Ankle Int 2002; 23: 496502. [CrossRef]

15. Cook E, Cook J, Rosenblum B, Landsman A, Giurini J, Basile P. Meta-analysis of first metatarsophalangeal joint implant arthroplasty. J Foot Ankle Surg 2009; 48: 180-90. [CrossRef]

16. Brewood AFM, Griffiths, J.C. The long term results of silicone stem Silastic arthroplasty of the great toe. J R Coll Surg Edinb 1985; 30: 161 .
17. Esway JE, Conti SF. Joint Replacement in the Hallux Metatarsophalangeal Joint. Foot Ankle Clin 2005; 10: 97-115. [CrossRef]

18. Duncan NS, Farrar NG, Rajan RA. Early results of first metatarsophalangeal joint replacement using the ToeFit-Plus prosthesis. J Foot Ankle Surg 2014; 53: 265-8. [CrossRef]

19. Taranow WS, Moutsatson MJ, Cooper JM. Contemporary Approaches to Stage II and III Hallux Rigidus: The Role of Metallic Hemiarthroplasty of the Proximal Phalanx. Foot Ankle Clin 2005; 10: 713-28. [CrossRef]

20. Giza E, Sullivan M, Ocel D, Lundeen G, Mitchell M, Frizzell L. First metatarsophalangeal hemiarthroplasty for hallux rigidus. Int Orthop 2010; 34: 1193-8. [CrossRef] 